\title{
Review for POR MAIS HUMANIDADE NA EDUCAÇÃO
}

\author{
Ivone Maria Mendes Silva ${ }^{1}$ \\ ${ }^{1}$ Ensino \& Pesquisa
}

September 12, 2020

Resumo: Este é um Grupo de Revisores de pré-impressão da Revista Ensino \& Pesquisa.

Parecer emitido por: Prof. ${ }^{\text {a }}$ Dra. Ivone Maria Mendes Silva - Universidade Federal da Fronteira Sul/UFFS Campus Erechim

O artigo "Por mais humanidade na educação", de Marcos Sardá Vieira, propõe-se a discutir "o papel das Ciências Humanas enquanto campo de conhecimento fundamental para a formação crítica e a compreensão dos fenômenos sociais", demonstrando a importância de se abordar o tema em questão considerando sua complexidade e as estreitas conexões que mantém com outras dimensões e processos (políticos, econômicos, educacionais etc.) da realidade social. Para isso, parte da análise de textos acadêmicos e reportagens publicadas pela imprensa nacional e internacional, compondo uma análise que nos permite perspectivar o cenário mais abrangente no qual a discussão se insere.

O artigo apresenta reflexões indispensáveis a uma análise crítica da realidade atual da educação superior brasileira, ao contemplar especialmente a relação entre educação, economia e questões de ordem políticoideológica. Essas reflexões assinalam como o processo de desvalorização das Ciências Humanas pode ter efeitos negativos para a sociedade como um todo. Isso porque a construção de um sistema educacional que seja capaz de oferecer à população uma formação integral, transformadora e de qualidade depende do conhecimento produzido pela área de Humanidades e seus diversos profissionais (historiadores, sociólogos, filósofos e outros especialistas).

Cabe lembrarmos, como destaca o autor, que esse processo de desvalorização das Ciências Humanas tem sido, em nosso país e em muitos outros, catalisado por decisões/ações de governantes e formuladores de políticas públicas que buscam respaldo no discurso do desenvolvimento técnico e da produtividade.

Nesse sentido, somos convidados/as a problematizar qual é o contexto de produção dos discursos que convertem a racionalidade técnica e financeira em racionalidade política. E mais: que relações de poder sustentam esses discursos. Assim, não é fortuito que coexistam, no Brasil atual, processos como a expansão do ensino superior privado, a imposição de cortes orçamentários às universidades públicas, ao mesmo tempo em que assistimos à intensificação das tensões e disputas sociopolíticas relacionadas à polarização política e à ascensão do conservadorismo e suas pautas, dentre outras variáveis que compõem o complexo cenário no qual estamos inseridos/as.

Assim, o artigo apresenta argumentos e suscita questionamentos relevantes, que podem nos municiar tanto no exercício de analisar criticamente discursos que, como os acima referidos, tem ganhado força na atualidade, quanto na reflexão sobre as mudanças que se fazem necessárias nesse cenário para que o exercício da democracia não seja colocado em risco.

Em consonância com essas observações, recomendo a publicação do artigo.

Erechim, 19 de agosto de 2020 